\title{
UJI AKTIVITAS ANTIMIKROBA EKSTRAK DAN FRAKSI SPONS Liosina paradoxa DARI PERAIRAN DESA TUMBAK MINAHASA TENGGARA TERHADAP PERTUMBUHAN MIKROBA Staphylococcus aureus, Escherichia coli, DAN Candida albicans.
}

\author{
Walen Efata Oeiyano ${ }^{1)}$, Herny E. Simbala ${ }^{1)}$, Henky Rotinsulu ${ }^{1)}$ \\ ${ }^{1)}$ Program Studi Farmasi Fakultas MIPA UNSRAT Manado
}

\begin{abstract}
Sponges are marine animals, which contain active compounds known to have potential in the pharmaceutical field, including the antimicrobials. The purpose of this study was to determine the activity of microorganism growth inhibitors from the sponge Liosina paradoxa against microbes Staphylococcus aureus, Escherichia coli, and Candida albicans. Samples were extracted by maceration method with ethanol solvent and fractionation using methanol, chloroform, and n-hexane solvents. Antimicrobial activity was carried out by agar diffusion method (Kirby and Bauer). Methanol fractions of sponge Liosina paradoxa showed the greatest antimicrobial activity against Escherichia coli with an average value of $11.33 \mathrm{~mm}$, and categorize as strong, chloroform fraction was $7.33 \mathrm{~mm}$ and categorize as medium, and n-hexane fraction was $7.16 \mathrm{~mm}$ and categorize as medium, ethanol extracts was $7.83 \mathrm{~mm}$ and categorize as moderate antimicrobial activity.
\end{abstract}

Keywords: Liosina paradoxa, Antimicrobial, Staphylococcus aureus, Escherichia coli, Candida albicans.

\begin{abstract}
ABSTRAK
Spons merupakan merupakan hewan laut yang mengandung senyawa aktif yang diketahui berpotensi dalam bidang farmasi, diantaranya sebagai antimikroba. Tujuan dari penelitian ini yaitu untuk mengetahui aktivitas penghambat pertumbuhan mikroorganisme dari spons Liosina paradoxa terhadap mikroba Staphylococcus aureus, Escherichia coli, dan Candida albicans.Sampel diekstraksi dengan metode maserasi dengan pelarut etanol dan fraksinasi menggunakan pelarut metanol, kloroform, dan n-heksan. Aktivitas antimikroba dilakukan dengan metode difusi agar (Kirby and Bauer). Fraksi metanol spons Liosina paradoxa menunjukkan aktivitas antimikroba paling besar terhadap Escherichia coli dengan nilai rata-rata 11,33 mm, dengan kategori kuat, fraksi kloroform 7,33 mm kategori sedang, fraksi n-hexan 7,16 mm kategori sedang, ekstrak etanol 7,83 mm kategori aktivitas antimikroba sedang.
\end{abstract}

Kata kunci: Liosina paradoxa, antimikroba, Staphylococcus aureus ,Escherichia coli, Candida albicans. 


\section{PENDAHULUAN}

Spons adalah organisme laut yang memiliki potensi cukup besar dalam menghasilkan senyawa aktif. Didunia diduga terdapat sekitar 10.000 spesies spons dan diperkirakan sekitar 200 spesies hidup di ekosistem terumbu karang Asia Tenggara (Dahuri et al., 2001). Spons dilaporkan memiliki aktivitas antikanker, antimikroba dan antiparasit (Amir dan Budianto, 1996). Spons merupakan salah satu komponen biota penyusun terumbu karang yang mempunyai potensi bioaktif yang belum banyak dimanfaatkan. Hewan laut ini mengandung senyawa aktif yang persentase keaktifannya lebih besar dibandingkan dengan senyawa-senyawa yang dihasilkan oleh tumbuhan darat (Suparno, 2005).

Mikroba patogen merupakan salah satu penyebab penyakit pada manusia dan makhluk hidup lainnya (Juariah et al., 2014). Berbagai penelitian menunjukkan bahwa organisme laut memiliki potensi yang sangat besar dalam menghasilkan senyawa-senyawa aktif yang dapat digunakan sebagai bahan baku obat. Beberapa organisme laut yang diketahui dapat menghasilkan senyawa aktif, salah satunya adalah ascidians. Organisme ini diketahui dapat menghasilkan sejumlah besar produk laut yang bersifat alami, juga mampu menunjukkan keragaman senyawa kimia yang sangat besar (Thakur dan Muller, 2004).

Staphylococcus aureus merupakan bakteri Gram positif berbentuk bulat, tersusun dalam kelompok-kelompok yang tidak teratur seperti buah anggur, fakultatif anaerob, tidak membentuk spora dan tidak bergerak. Bakteri ini tumbuh pada suhu optimum $37{ }^{\circ} \mathrm{C}$, tetapi membentuk pigmen paling baik pada suhu kamar $\left(20-25^{\circ} \mathrm{C}\right)$.
Koloni pada perbenihan padat berwarna abu-abu sampai kuning keemasan, berbentuk bundar, halus, menonjol dan berkilau (Brooks et al., 1995).

Escherichia coli merupakan flora normal didalam intestin. Bakteri ini dapat menyebabkan infeksi saluran kencing yang merupakan infeksi terbanyak (80\%), gastroenteritis dan meningitis pada bayi, peritonitis, infeksi luka, kolesistitis, syok bakterimia karena masuknya organisme ke dalam darah dari uretra, kateterisasi atau sitoskopi atau dari daerah sepsis pada abdomen atau pelvis (Gibson, 1996).

Candida albicans merupakan jamur yang mempunyai kemampuan untuk tumbuh dalam dua bentuk yang berbeda yaitu blastopore (blasroconidia) adalah bentuk fenotip yang bertanggung jawab dalam tranmisi dan penyebaran, serta germinated yeast. Oleh karena itu Candida disebut jamur dimorfik (Tortora, 2001). Perbedaan ini tergantung pada faktor eksternal yang mempengaruhi selama proses pertumbuhan berlangsung. Bentuk fenotip dapat menginvasi jaringan dan menimbulkan simptomatik karena dapat menghasilkan mycelia (Wibowo, 2010).

\section{METODOLOGI PENELITIAN}

Alat

Alat yang digunakan dalam penelitian ini yaitu tabung oksigen, snorkel, fins, masker, sarung tangan, gunting, pisau, zipper bag, botol $600 \mathrm{ml}$, talenan, cool box, kamera , Erlenmeyer (Pyrex), corong, oven, timbangan analitik, spatula, corong pisah, gelas ukur, gelas kimia (Pyrex), cawan petri, autoklaf, pinset, pembakar spritus, vortex mixer, micro tubes, batang pengaduk, laminar air flow, rak tabung reaksi, tabung reaksi, lemari pendingin, 
inkubator, cakram (paper disc), mikropipet, digital caliper, kertas label, spidol permanen, vacum.

\section{Bahan}

Bahan-bahan yang digunakan yaitu Spons Liosina paradoxa, mikroba uji Staphylococcus aureus, Escherichia coli, Candida albicans, etanol, akuades, nheksan, kloroform, metanol, pepton, beef extract,natriumklorida, agar, kloramfenikol paper disc, tissue, aluminium foil, plastic wrap, kertas saring.

\section{Prosedur penelitian}

\section{Ekstraksi}

Ekstrak Spons Liosina Paradoxa sebanyak $500 \mathrm{~g}$ diekstraksi dengan menggunakan cara maserasi. Sampel dipotong kecil-kecil dengan ukuran $1 \mathrm{~cm}^{2}$ lalu dimasukkan ke dalam botol dan direndam dengan larutan etanol 96\% sampai sampel terendam secara keseluruhan, sampel di kocok- kocok dan dibiarkan selama 24 jam. Sampel yang direndam disaring dengan menggunakan kertas saring menghasilkan filtrat 1 dan debris 1. Debris 1 direndam kembali dengan etanol 96\% sampai terendam semuanya, debris dikocok - kocok dan dimaserasi selama 1x24 jam. Diulangi cara yang sama sampai memperoleh 3 filtrat dan 3 debris. Campurkan filtrat 1, 2, dan 3 yang diperoleh menjadi satu. Filtrat dievaporasi menggunakan oven dengan suhu $40^{\circ} \mathrm{C}$ hingga memperoleh ekstrak kasar spons Liosina paradoxa dan timbang dengan menggunakan timbangan analitik. Ekstrak kasar etanol spons Liosina paradoxa sebanyak $14,50 \mathrm{~g}$, selanjutnya ekstrak kasar etanol digunakan dalam fraksinasi dan pengujian daya hambat antimikroba.

\section{Fraksinasi}

Sebanyak 3,0 g ekstrak kasar spons Liosina paradoxa dimasukkan kedalam gelas kimia, kemudian dilarutkan dengan metanol $80 \%$ sebanyak $100 \mathrm{~mL}$. Setelah tercampur, dimasukan kedalam corong pisah dan ditambahkan pelarut n-heksan sebanyak $100 \mathrm{~mL}$ setelah itu dikocok dalam corong pisah sampai homogen. Dibiarkan sampai terbentuk lapisan metanol dan lapisan n-heksan, kemudian masing-masing lapisan ditampung dalam erlenmeyer yang berbeda. Lapisan nheksan kemudian dikeringkan menggunakan oven dengan suhu $40^{\circ} \mathrm{C}$, lalu ditimbang dan diperoleh fraksi nheksan sebanyak 0,029 g. Selanjutnya, lapisan metanol ditambahkan akuades sebanyak $100 \mathrm{~mL}$ kemudian dipartisi dengan pelarut kloroform dengan perbandingan $1: 1 \mathrm{v} / \mathrm{v}$ dalam corong pisah, setelah itu dikocok kembali sampai homogen. Dibiarkan sampai tebentuk dua lapisan yaitu lapisan metanol dan kloroform, kemudian masing-masing lapisan ditampung dalam erlenmeyer yang berbeda. Lapisan kloroform selanjutnya dikeringkan menggunakan oven dengan suhu $40^{\circ} \mathrm{C}$, lalu ditimbang berat sampel dan diperoleh fraksi kloroform sebanyak 0,037 g. Lapisan metanol kemudian dikeringkan menggunakan oven dengan suhu $40^{\circ} \mathrm{C}$, lalu ditimbang dan diperoleh fraksi metanol sebanyak 0,33 g. Ketiga fraksi yang diperoleh akan digunakan dalam pengujian antimikroba.

\section{Sterilisasi Alat}

Alat-alat gelas yang digunakan dalam penelitian aktivitas antimikroba ini disterilkan terlebih dahulu dengan menggunakan autoklaf pada suhu $121{ }^{\circ} \mathrm{C}$ 
selama 15 menit, pinset dibakar dengan pembakaran di atas api langsung dan media disterilkan di autoklaf pada suhu $121^{\circ} \mathrm{C}$ selama 15 menit (Ortez, 2005).

\section{Pembuatan Media Cair B1}

Pepton $0,5 \mathrm{~g}$, ekstrak daging (beef extract) 0,3 g, natrium klorida 0,3 g, nutrient agar $1,5 \mathrm{~g}$ dan dilarutkan dalam akuades sebanyak $100 \mathrm{~mL}$ menggunakan Erlenmeyer, dikocok sampai homogen. Media yang telah homogen kemudian disterilkan dengan menggunakan autoklaf pada suhu $121^{\circ} \mathrm{C}$ selama 15 menit. Media agar B1 siap digunakan untuk uji aktivitas antimikroba (Ortez, 2005).

\section{Kultur Mikroba}

Mikroba yang digunakan yaitu bakteri Escherichia coli, Staphylococcus aureus dan jamur Candida albicans. Masing-masing mikroba diambil dari biakan murni menggunakan mikropipet sebanyak $100 \mu \mathrm{L}$ dan dimasukkan ke dalam masing-masing tabung reaksi yang sudah berisi media cair B1 sebanyak $1 \mathrm{ml}$ dan kemudian ditutup menggunakan aluminium foil. Setelah itu, diinkubasi dalam inkubator pada suhu $37^{\circ} \mathrm{C}$ selama 1 x 24 Jam (Dwijendra et al, 2014).

\section{Pembuatan Media Uji}

Pepton 0,5 g, beef extract 0,3 g, natrium klorida $0,3 \mathrm{~g}$, agar $1,5 \mathrm{~g}$ dan akuades sebanyak $100 \mathrm{ml}$ diaduk sampai homogen kemudian disterilkan di autoklaf pada suhu $121^{\circ} \mathrm{C}$ selama 15 menit (Dwijendra et al, 2014).

\section{Pembuatan Larutan Uji}

Larutan uji dibuat dengan cara $1 \mathrm{mg}$ ekstrak kasar Spons Liosina paradoxa dilarutkan dalam $200 \mu \mathrm{L}$ metanol dan dikocok hingga homogen menggunakan vortex. Perlakuan yang sama dilakukan pada fraksi n-heksan, fraksi kloroform dan fraksi metanol (Ortez, 2005).

\section{Pembuatan Kontrol Positif dan Kontrol Negatif}

Kontrol postif yang digunakan dalam penelitian ini yaitu Kloramfenikol Paper disc dan Kontrol negatif yang digunakan dalam penelitian ini yaitu menggunakan pelarut metanol, dengan cara membuat larutan stok metanol dengan mengambil sebanyak $200 \mu \mathrm{l}$ metanol kemudian ditotolkan pada paper disc

\section{Pengujian Aktivitas Antimikroba}

Metode yang digunakan dalam penelitian ini yaitu metode difusi agar (disc diffusion Kirby and Bauer). Pada pengujian aktivitas antimikroba ini, cakram (paper disc) yang digunakan berukuran $6 \mathrm{~mm}$ dengan daya serap $50 \mu \mathrm{L}$ tiap cakram. Sebanyak $300 \mu \mathrm{L}$ mikroba yang telah dikultur, dipipet dan diinokulasi pada $30 \mathrm{ml}$ media agar lalu diaduk hingga homogen dan kemudian dituangkan ke dalam cawan petri dan tunggu sampai media agar mengeras. Kemudian, larutan uji yang telah disiapkan ditotolkan pada masing-masing cakram dengan menggunakan mikropipet. Setelah agar mengeras, kertas cakram yang telah ditotolkan sampel Liosina paradoxa kontrol positif dan kontrol negatif diletakkan ke dalam cawan petri dengan menggunakan pinset. Selanjutnya, cawan petri diberi label dan diinkubasi dalam inkubator pada suhu $37^{\circ} \mathrm{C}$ selama 1 x 24 Jam (Ortez, 2005).

Pengamatan dan Pengukuran Diameter Zona Hambat 
Pengamatan dilakukan setelah 24 jam masa inkubasi. Daerah pada sekitaran cakram menunjukkan kepekaan mikroba terhadap antibiotik atau bahan antimikroba yang digunakan sebagai bahan uji yang dinyatakan dengan diameter zona bening. Diameter zona bening diukur menggunakkan digital caliper. Zona bening yang telah diukur ,dikategorikan berdasarkan pedoman Davis dan Stout (1971).

\section{Pengolahan dan Analisis Data}

Teknik pengolahan data dilakukan dengan model penyajian dalam bentuk tabel dan gambar. Uji aktivitas antibakteri di ukur dengan menggunakan jangka sorong skala millimeter berdasarkan zona hambat yang terbentuk, kemudian dirataratakan dari tiga kali pengujian.

\section{HASIL DAN PEMBAHASAN Ekstraksi}

Sampel Spons Liosina paradoxa yang diambil dari perairan desa Tumbak, minahasa Tenggara dipotong kecil-kecil dengan ukuran $1 \mathrm{~cm}^{2}$, hal ini dilakukan dengan tujuan agar memperkecil luas permukaan sampel, karena semakin kecil permukaan sampel maka akan semakin luas permukaan yang akan berinteraksi dengan pelarut sehingga senyawa yang akan ditarik oleh pelarut pun semakin banyak. Selanjutnya sampel spons Liosina paradoxa di ekstraksi dengan menggunakan metode maserasi. Metode maserasi digunakan karena peralatan dan pengerjaan yang sederhana dan mudah dilakukan. Perendaman sampel dalam maserasi dapat membuat dinding sel dari sampel pecah dan membuat senyawasenyawa yang ada dalam sampel yang terdapat dalam sitoplasma akan tertarik oleh pelarut. Dinding sel pecah di karenakan adanya perbedaan konsentrasi di dalam dan di luar sel. Konsentrasi di luar sel lebih tinggi dibandingkan konsentrasi di dalam sel yang rendah sehingga dinding sel pecah karena tidak bisa menahan tekanan dari perbedaan konsentrasi (Harborne, 1996). Pemilihan cara maserasi juga bertujuan untuk menghindari terjadinnya penguraian zat aktif yang terkandung dalam sampel oleh pemanasan tinggi.

Pelarut yang digunakan untuk penyarian zat aktif adalah etanol $96 \%$ karena etanol merupakan larutan penyari yang bersifat universal, mudah didapat dan selektif sehingga penyarian dengan menggunakan pelarut etanol diharapkan mampu menarik semua zat-zat atau senyawa yang bersifat polar dan non polar yang terkandung dalam sampel, selain itu etanol tidak toksik serta ekonomis.

Proses ekstraksi dilakukan selama 3x24 jam dan setiap 24 jam ekstrak disaring dan dimaserasi kembali dengan pelarut yang baru hal ini disebut dengan remaserasi. Remaserasi dilakukan agar senyawa aktif dalam sampel dapat ditarik secara optimum (Huliselan et al, 2015).

Hasil ekstrak Spons $\begin{array}{r}\text { Liosina } \\ \text { diuapkan }\end{array}$
paradoxa selanjutnya
menggunakan oven dengan suhu $40^{\circ} \mathrm{C}$,
penguapan ekstrak ini dimaksudkan agar
air dan pelarut yang tersisa dalam ekstrak
akan menguap. Menggunakan suhu $40^{\circ} \mathrm{C}$
bertujuan untuk tetap menjaga senyawa
bioaktif yang terdapat dalam filtrat karena
biasanya senyawa-senyawa bioaktif tidak
tahan terhadap suhu tinggi (Kowal et al.,
2018). Massa ekstrak beserta rendemen
yang dihasilkan dalam proses ekstraksi
ditunjukkan pada Tabel 1 .


Tabel 1. Rendemen ekstrak Spons Liosina paradoxa

\begin{tabular}{cccc}
\hline No. & Sampel & $\begin{array}{c}\text { Rendemen } \\
(\%)\end{array}$ & $\begin{array}{c}\text { Warna } \\
\text { Sampel }\end{array}$ \\
\hline 1. & Ektsrak & 2,9 & $\begin{array}{c}\text { Cokelat } \\
\text { Pekat }\end{array}$ \\
\hline
\end{tabular}

\section{Fraksinasi}

Hasil ekstrak kasar Spons Liosina paradoxa yang diperoleh selanjutnya di lanjutkan ke tahap fraksinasi. Fraksinasi yang digunakan yaitu fraksinasi cair - cair berdasarkan perbedaan tingkat kepolaran dari setiap pelarut yaitu dimulai dari pelarut n-heksan, kloroform dan metanol. Pada proses fraksinasi dilakukan pengocokan sebelum didapat 2 lapisan pelarut hal ini bertujuan agar kandungan kimia yang terdapat dalam Spons Liosina paradoxa secara selektif dapat ditarik oleh pelarut yang digunakan. Masing - masing pelarut akan memisahkan kelompok kandungan senyawa berdasarkan tingkat kepolaran, ekstrak disari dengan pelarut yang non polar, kemudian disari dengan pelarut yang semi polar dan pelarut polar (Wewengkang et al., 2014). Pada saat fraksinasi dengan pelarut- pelarut yang berbeda kepolaran, akan terbentuk 2 lapisan, dimana pelarut dengan masa jenis yang lebih besar akan berada di bagian bawah dan pelarut dengan masa jenis kecil akan berada di lapisan atas. Kemudian fraksi yang diperoleh di uapkan dengan oven pada suhu $40^{\circ} \mathrm{C}$ dan kemuidan digunakan untuk uji aktivitas antimikroba. Massa fraksi beserta rendemen yang dihasilkan dalam proses fraksinasi ditunjukkan pada Tabel 2.
Tabel 2. Rendemen fraksi Spons Liosina paradoxa

\begin{tabular}{|c|c|c|c|}
\hline No. & Sampel & $\begin{array}{c}\text { Rendemen } \\
(\%)\end{array}$ & $\begin{array}{l}\text { Warna } \\
\text { Sampel }\end{array}$ \\
\hline 1. & $\begin{array}{c}\text { Fraksi } \\
\text { Heksan }\end{array}$ & 0,96 & $\begin{array}{c}\text { Cokelat } \\
\text { Muda }\end{array}$ \\
\hline 2. & $\begin{array}{c}\text { Fraksi } \\
\text { Kloroform }\end{array}$ & 1,2 & $\begin{array}{c}\text { Coklat } \\
\text { Tua }\end{array}$ \\
\hline 3. & $\begin{array}{c}\text { Fraksi } \\
\text { Metanol }\end{array}$ & 11 & $\begin{array}{c}\text { Kuning } \\
\text { tua }\end{array}$ \\
\hline
\end{tabular}

Terdapat perbedaan nilai rendemen ini disebabkan oleh perbedaan jenis pelarut yang digunakan. Dimana, pelarut yang berbeda akan melarutkan senyawasenyawa yang berbeda, sehingga jumlah fraksi yang dihasilkan pun juga berbeda (Mujipradhana et al, 2018). Terlihat dari hasil rendemen yang dihasilkan fraksi metanol lebih tinggi hasil rendemenya yaitu $93 \%$. Hal ini dikarenakan pelarut metanol mampu mengekstrak lebih banyak senyawa - senyawa aktif dari sampel sehingga senyawa - senyawa aktif yang terdapat dalam spons Liosina paradoxa lebih bersifat polar. Rendemen ekstrak hasil maserasi dengan pelarut yang berbeda akan menghasilkan rendemen yang berbeda dan nilai rendemen yang dihasilkan dari ekstrak metanol diduga dipengaruhi sifat larutan tersebut yang dapat melarutkan hampir semua komponen bahan aktif (Priyanto , 2012).

\section{Uji Aktivitas Antimikroba}

Pengujian aktivitas antimikroba dilakukan dengan menggunakan metode difusi agar (difusi Kirby-Bauer yang telah dimodifikasi). Pengujian dilakukan terhadap bakteri Staphylococcus aureus 
yang mewakili bakteri Gram positif, Escherichia coli mewakili bakteri Gram negatif dan Candida albicans yang mewakili Jamur. Metode ini dipilih karena dapat digunakan untuk melihat sensitivitas berbagai jenis mikroba terhadap antimikroba pada konsentrasi tertentu (Akhyar, 2010).

Uji aktivitas antimikroba dilakukan pengamatan selama $1 \times 24$ jam masa inkubasi pada suhu $37^{\circ} \mathrm{C}$ dengan masingmasing 3 kali penggulangan untuk tiap mikroba. Konsentrasi yang digunakan 250 $\mu \mathrm{g}$, dengan daya serap masing- masing paper disc $50 \mu \mathrm{L}$. Aktivitas yang terbentuk terlihat dari adanya zona bening di sekitaran cakram yang berukuran $6 \mathrm{~mm}$, membuktikan bahwa ekstrak dan fraksi dari spons Liosina paradoxa yang diujikan menunjukkan kepekaan terhadap masing masing mikroba dan antibiotik kloramfenikol digunakan sebagai kontrol positif.

Tabel 3. Hasil Pengukuran Rata-Rata Diameter Daya Antimikroba

\begin{tabular}{|c|c|c|c|c|c|c|c|}
\hline \multicolumn{2}{|c|}{ Milkroarganisme } & \multirow{2}{*}{$\begin{array}{c}\text { Fraksi } \\
\text { MeOH }\end{array}$} & \multirow{2}{*}{$\begin{array}{c}\text { Fraksi } \\
\text { CHCb }\end{array}$} & \multirow{2}{*}{$\begin{array}{c}\begin{array}{c}\text { Fraksi } \\
\text { n-heksan }\end{array} \\
7,15\end{array}$} & \multirow{2}{*}{$\begin{array}{c}\begin{array}{c}\text { Ekstra } \\
\text { k } \\
\text { EtOH }\end{array} \\
715\end{array}$} & \multirow{2}{*}{$\mathbf{K}^{+}$} & \multirow{2}{*}{$\mathbf{K}$} \\
\hline \multirow{4}{*}{ S.aureus: } & I & & & & & & \\
\hline & II & 12,0 & 7,5 & 7,30 & 7,0 & \multirow{3}{*}{20,00} & \multirow{3}{*}{0,0} \\
\hline & III & 10,0 & 7,0 & 7,0 & 7,0 & & \\
\hline & $\bar{x}$ & 11,16 & 7,16 & 7,15 & 7,05 & & \\
\hline \multirow{4}{*}{ E.coli } & I & 11,0 & 7.0 & 7,5 & 7,5 & \multirow{4}{*}{23,10} & \multirow{4}{*}{0,0} \\
\hline & II & 11.0 & 8.0 & 7,0 & 8,0 & & \\
\hline & III & ns. & 7,0 & 7,0 & 8,0 & & \\
\hline & $\bar{x}$ & 11,33 & 3,3 & 7,16 & 7,83 & & \\
\hline \multirow{4}{*}{ C.elbicans } & I & 7,0 & 6,5 & 6.5 & 6,5 & \multirow{4}{*}{$17, \infty 0$} & \multirow{4}{*}{0,0} \\
\hline & II & 7,30 & 6,0 & 6,5 & 6.5 & & \\
\hline & III & 7,5 & 6,10 &. & . & & \\
\hline & $\bar{x}$ & 7,20 & 6.2 & 6,5 & 6.5 & & \\
\hline
\end{tabular}

Kriteria yang digunakan dalam penelitian ini untuk menggolongkan daya hambat dari kontrol uji dan bahan uji
Spons Liosina paradoxa menggunkana kriteria kekuatan antibakteri menurut Davis dan Stout yaitu dapat dilihat pada Tabel 4 dibawah ini:

\begin{tabular}{cc}
$\begin{array}{c}\text { Tabel 4. Kategori Kekuatan Daya } \\
\text { Antimikroba }\end{array}$ \\
\hline $\begin{array}{c}\text { Diameter Zona } \\
\text { Bening }(\mathrm{mm})\end{array}$ & Kategori \\
\hline$>\mathbf{2 0}$ & Sangat Kuat \\
$\mathbf{1 0}-\mathbf{2 0}$ & Kuat \\
$\mathbf{5}-\mathbf{1 0}$ & Sedang \\
$<\mathbf{5}$ & Lemah \\
\hline
\end{tabular}

Pada pengujian ini digunakan control positif yaitu kloramfenikol dengan spectrum kerja yang luas. Penggunaan kontrol positif berfungsi sebagai kontrol dari zat uji, dengan membandingkan diameter daerah hambat yang terbentuk (Dwijendra et al, 2014). Dari hasil yang diperoleh kontrol positif kloramfenikol menunjukan diameter zona hambat paling besar $(23,10 \mathrm{~mm})$ dibandingkan dengan ekstrak dan fraksi sampel Spons Liosina paradoxa.

Kontrol negatif yang digunakan yaitu metanol, dari hasil yang diperoleh metanol tidak menunjukan adanya zona hambat pada pengujian yang dilakukan pada tiap mikroba uji. Sehingga dapat diketahui, bahwa aktivitas yang didapat adalah murni dari senyawa aktif yang terkandung pada ekstrak dan fraksi sampel Spons Liosina paradoxa.

Berdasarkan hasil yang diperoleh, pada fraksi metanol menunjukkan bahwa diameter zona bening yang terbentuk pada bakteri Staphylococcus aureus di kategorikan kuat yaitu 11,16 mm , pada Escherichia coli juga dikategorikan kuat yaitu 11,33 mm dan pada jamur Candida albicans dikategorikan sedang yaitu 7,00 $\mathrm{mm}$. Dari hasil yang didapat menunjukkan bahwa fraksi metanol memiliki senyawa 
aktif yang hanya dapat menghambat pertumbuhan bakteri Escherichia coli serta Staphylococcus aureus dan memiliki aktivitas untuk menghambat pertumbuhan jamur Candida albicans. Fraksi metanol spons Liosina paradoxa memiliki spektrum kerja yang luas karena dapat menghambat pertumbuhan bakteri baik gram positif ,gram negatif maupun jamur.

Pada fraksi kloroform, diperoleh hasil yang menunjukkan bahwa diameter zona bening yang terbentuk pada bakeri Staphylococcus aureus memiliki kekuatan antimikroba sedang yaitu 7,16 mm, pada bakteri Escherichia coli memiliki kekuatan antimikroba sedang yaitu $7,30 \mathrm{~mm}$ dan pada jamur Candida albicans juga memiliki aktivitas antimikroba sedang yaitu $6,50 \mathrm{~mm}$. Hal ini menunjukkan bahwa fraksi kloroform memiliki senyawa aktif yang dapat menghambat pertumbuhan dari ketiga mikroba tersebut dengan kekuatan antimikroba sedang.

Pada fraksi n-heksan, hasil yang didapat dengan diameter zona bening yang terbentuk pada bakteri Staphylococcus aureus dan bakteri Escherichia coli memiliki kekuatan antimikroba yang sedang yaitu 7,21 $\mathrm{mm}$ dan 7,16 mm. Untuk jamur Candida albicans kekuatan untuk antimikroba sedang yaitu $6,5 \mathrm{~mm}$. Hal ini menunjukkan bahwa fraksi n-hexan dari sampel spons liosina paradoxa memiliki senyawa aktif yang hanya dapat menghambat pertumbuhan mikroba dan memiliki spektrum kerja yang luas karena dapat menghambat pertumbuhan bakteri gram positif, gram negatif dan mengh ambat pertumbuhan jamur.

Pada ekstrak etanol spons liosina paradoxa, hasil yang diperoleh, menunjukkan adanya aktivitas antimikroba pada Staphylococcus aureus yaitu 7,05 mm termasuk kategori aktivitas sedang, pada Escherichia coli termasuk juga kategori sedang yaitu 7,83 $\mathrm{mm}$ dan pada jamur Candida albicans menunjukan aktivitas dengan kategori sedang yaitu 6,5 $\mathrm{mm}$.

Hasil yang didapat Dari uji aktivitas anti mikroba pada mikroba uji yaitu Staphylococcus aureus, Escherichia coli dan Candida albicans. Diperoleh bahwa semua ekstrak dan fraksi spons liosina paradoxa memiliki aktivitas untuk penghambat pertumbuhan mikroba Staphylococcus aureus, Escherichia coli dan Candida albicans. Aktivitas antimikroba yang kuat terdapat pada fraksi metanol, dan aktivitas sedang terdapat pada fraksi kloroform, fraksi n-hexan dan ekstrak etanol. Hal ini menunjukkan bahwa senyawa polar pada sampel spons Liosina paradoxa memiliki aktivitas lebih baik dari pada senyawa non polar sampel.

\section{KESIMPULAN}

Hasil penelitian yang diperoleh menunjukkan bahwa ekstrak dan fraksi dari Spons Liosina paradoxa memiliki aktivitas untuk menghambat bakteri Escherichia coli serta Staphylococcus aureus dan jamur Candida albicans. Fraksi metanol mem iliki aktivitas untuk menghambat bakteri Staphylococcus aureus dan Escherichia coli dengan kategori daya hambat kuat, sedangkan untuk fraksi kloroform, fraksi n-hexan dan ekstrak etanol hanya memiliki aktivitas daya hambat sedang terhadap Escherichia coli serta Staphylococcus aureus dan jamur Candida albicans.

\section{SARAN}

Perlu dilakukan penelitian lebih lanjut terhadap Spons Liosina paradoxa 
dengan metode pengujian yang berbeda dan uji aktivitas lainnya agar dapat mengetahui manfaat lain selain aktivitas antimikroba.

\section{DAFTAR PUSTAKA}

Amir, I., A. Budiyanto. 1996. Mengenal Spons Laut (Demospongiae) Secara Umum. Oseana. 21(2) 1531.

Akhyar. 2010. Uji Daya Hambat dan Analisis KLT Bioautografi Ekstrak Akar dan Buah Bakau ( Rhizophora stylosa Griff.) Terhadap Vibrio Harveyi [skripsi]. Fakultas Farmasi Universitas Hasanuddin, Makassar

Jawetz, E., J.L. Melnick., F.A. Adelberg., G.F. Brooks., J.S. Butel., dan L.N. Ornston.1995.MikrobiologiKedokte ran. Alih bahasa oleh Nugroho dan R.F.Maulany. EGC, Jakarta.

Davis, W. W., Stout, T. R. 1971. Disc Plate Method of Microbiological Antib iotic Assay. Appl. Microbiol. 4(22): 666-670.

Dahuri, R., Jacub Rais., Sapta Putra Ginting, dan M.J., Sitepu. 2001. Pengelolaan Sumber daya Wilayah Pesisir dan Lautan secara Terpadu. PT Pradnya Paramita, Jakarta.

Dwijendra, I. M., D. S. Wewengkang., F. Wehantou. 2014. Aktivitas Antibakteri dan Karakterisasi Senyawa Fraksi Spons Lame llodysidea herbacea Manado. Pharmacon. 3(4): 1-9.

Gibson. 1996. Organisasi, Prilaku, Struktur, Proses. Jakarta: Erlangga.

Harbone, J.B. 1987. Metode Fitokimia Penuntun Modern Menganalisis Tumbuhan Edisi Kedua. ITB Press, Bandung.
Huliselan, Y. M., M. R. J. Runtuwene., D. S. Wewengkang. 2015. Aktivitas Antioksidan Ekstrak Etanol, Etil Asetat dan N-Heksan dari Daun Sesewanua,(Clerodendronsquamat um Vahl.). Pharmacon. 4(3): 155163.

Juariah, S. Suryanto, D. Jamilah, I. 2014. Altivitas Antibakteri Spesies Asterias Forbesi Terhadap Bebera pa Jenis Bakteri Patogen. Jurnal Berkala Perikanan Telubuk. 42(2) : 37-50

Kowal, A., Esther, A., Nickson, K., Kurniati, K., Henky, M., Deiske, H. 2018. Potensi antibakteri karang lunak lobophytum sp. Dari perairan pangalisang pulau bunaken terhadap bakteri Pseudomonas aeruginosa dan Staphylococcus aureus. Jurnal Ilmiah Platax. 6(2)

Mujipradhana, V., Defny, W., Edi, S. Aktivitas antimikroba dari ekstrak ascidian herdmania momus pada mikroba patogen manusia. Jurnal Ilmiah Farmasi 7(3).

Ortez, J. H. 2005. Disk Diffusion testing in manual of antimicrobial susce ptibility testing. Marie B. Coyle (Coord. Ed). American society for Microbiology, America.

Priyanto, R. A. 2012. Aktivitas Antioksidan Dan Komponen Bioaktif Pada Buah Bakau (Rhizophora mucronata Lamk.). [Skrips] Institut Pertanian Bogor.

Suparno. 2005. Kajian Bioaktif spons laut (forifera: Demospongiae) Suatu Peluang Alternative Pemanfaatan Ekosistem Karang Indonesia Dalam Bidang Farmasi. Institute Pertanian Bogor. 
Thakur, N.L., Muller, W.E.G. 2004.

Biotechnological Potential Of

ManrineSponge .Journal Current

Science. 86 : 1506-1512

Wewengkang, D., Deiske. S., Hengki. R. 2014. Karakterisasi dan bioaktif antibakteri senyawa spons Haliclona sp. dari teluk manado. Jurnal LPPM Bidang Sains dan Teknologi. 1(1).

Wibowo, S. 2010. Ilmu Pangan Nutrisi dan Mikrobiologi edisi ke-2. Rajawali Press, Jakarta. 